\title{
Aflatoxins in Poultry Nutrition
}

\author{
Ahmad ALHOUSEIN ${ }^{1}$, Yavuz GURBUZ ${ }^{1^{*}}$ \\ ${ }^{1}$ KSU, Faculty of Agriculture, Department of Animal Science, Kahramanmaras
}

\author{
Received (Geliş): 09.03.2015
}

Accepted (Kabul): 03.11.2015

\begin{abstract}
Aflatoxin is generated by mycotocins and it is causes a big losses and rasied the managament costs that's becuase of its extremely high toxicity on unit basis. Research during the last five decades has explored the negative effects of the aflatoxins on health of poultry and sometimes caused disease called Aflatoxciosis. They clamid it has bad effects in both broilers and layers. For example in broilers it is effects on immunity system, performance and gastro intestinal tract and in layers it is caused a decreasing in egg broduction and decreasing in hatching rate. Aflatoxins by effecting the poultry it makes a residue in tissues and organs in diffrent levels and may be caused acute or chronic effects to human health by consuming this tissue and organs and may be has toxcignic, carcinognic proprities that causes complicated issues for human.
\end{abstract}

Key Words: Aflatoxins, aflatoxciosis, broilers, layers, toxicity

\section{INTRODUCTION}

The word aflatoxin is the combination of 3 other word, a, for Aspergillus genus, fla, for the species Flavus and toxin meaning posion. The discover of the aflatoxin reterun to 1960 which resulted in the losses of thousand turkey poults in United Kingdom and still threat the poultry industry and make substantial economic losses

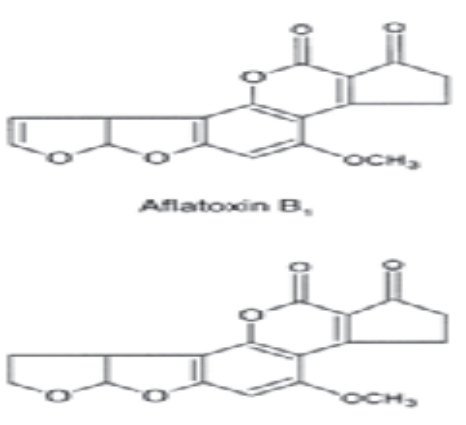

Anavoocin B,

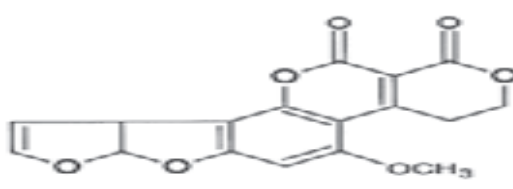

Aflatoxin $\mathrm{G}$,

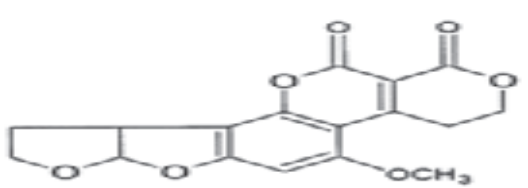

Aflatoxin $\mathrm{G}_{2}$ becuse of sub-lethal but toxic effect (Diaz and Murcia 2011). Aflatoxin (AF) is mycotoxins that are produced by different Aspergillus species such as A. Flavus, A.parasiticus and A.nominus. Secondary metabolatis of these fungi AF may contaminate the feedstuff especially corn, peanuts and cottonseed. Aflatoxin includes aflatoxin B1, B2, G1, G2, M1, M2 (Sumit et.al. 2010).

Figure 1. Chemical structure of AFB1, AFB2, AFM1, AFM2, AFG1 and AFG2 (Zain, 2011)

FDA creating guidelines for maximum toxin levels that can be safely feed to poultry and these limits make a roule in export and import and effect in international trade in grain.

Table 1. FDA's action levels for aflatoxin in poultry feed (Yunus et al. 2008)

\begin{tabular}{llcc}
\hline \multicolumn{1}{c}{ Class of Animal } & \multicolumn{1}{c}{ Feed } & Maximum Aflatoxin Level \\
\hline & & $(\mathrm{mg} / \mathrm{kg})$ & $(\mathrm{ppb})$ \\
\hline Immature poultry & Corn \& peanut products & 0.02 & 20 \\
Mature poultry & Corn \& peanut products & 0.1 & 100 \\
Poultry & Cottonseed meal & 0.3 & 300 \\
All animals & Other feeds & 0.02 & 20 \\
\hline
\end{tabular}

${ }^{1}$ Concentrations are reported as either ppm (parts per million) or ppb (parts per billion). Because of differences in international interpretation, metric concentrations are utilized in this publication. $1 \mathrm{mg} / \mathrm{kg}=1 \mathrm{ppm}=1000 \mathrm{ppb}$

\section{AFLATOXIN PROPERTIES}

All mycotoxins are low-molecular-weight natural products (i.e., small molecules). They can absorb low molecular weight nutrients, produce and secrete secondary metabolites, which are also relatively low molecular weight compounds but not associated with the process of growth and primary metabolism. Aflatoxins divided into the $B$ and $G$ groups based on their blue orgreen fluorescence under UV light when absorbed to solid substrates. A.parasiticus is the most toxigenic species; the majority of strains producing both $B$ and $G$ toxins (Van Egmond, 2004) by naturally occurring aflatoxins (as a group) and other 107 agents were evaluated as carcinogenic to humans (Group 1). There is sufficient evidence in humans for the carcinogenicity of aflatoxins, being liver cancer (hepatocellular carcinoma) the main effect. Aflatoxin M1, the metabolite of aflatoxin B1 found in milk of lactating mammals was classified in 
Group 2B a possibly carcinogenic to humans Carcinogenicity naturally occurring mixtures of aflatoxins B1, G1 and M1 is also demonstrated (Gowda et al. 2008). We noted from the table 2 that aflatoxins have carcinognic acting and may be effect the health of human.

Table 2. Main producing species and effects of aflatoxins

\begin{tabular}{lll}
\multicolumn{1}{c}{ Aflatoxins } & \multicolumn{1}{c}{ Main producing species } \\
\hline B1 & A. flavus, A. parasiticus, A. nomius, A. bombycis & \multicolumn{1}{c}{ Toxic effect } \\
B2 & A. flavus, A. parasiticus, A. nomius A. bombycis & Hepatotoxic, genotoxic immunomodulation \\
G1 & A. flavus, A. parasiticus, A. nomius A. bombycis & Sufficient evidence of carcinogenicity \\
G2 & A. flavus, A. parasiticus, A. nomius A. bombycis & Inadequate evidence for carcinogenicity \\
\hline
\end{tabular}

\section{EFFECT OF AFLATOXIN ON BROILERS}

There are many of studies that constrate on this title For example, feeding a high level $(3.5 \mathrm{mg} / \mathrm{kg}$ of feed $)$ of an AF mixture (i.e. 79\% AFB1, 16\% AFG1, 4\% AFB2, and $1 \%$ AFG2) to broilers; reduced their body weight, increased their liver and kidney weights (Smith et al.,
1996). Aflatoxins also increased blood urea-N and decreased serum levels of total protein, albumin, triglycerides and phosphorus and in other study they wiewed effect aflatoxins on broilers performance (Grenier and Applegate, 2011).

Table 3. Effect of feeding aflatoxin contaminated diet on serum biochemical parameters in broilers at five weeks of age (Rajau and Devegowde, 2000)

\begin{tabular}{cccc}
\hline $\begin{array}{c}\text { Aflatoxin } \\
300 \mathrm{ppb}\end{array}$ & $\begin{array}{c}\text { Total proteins } \\
(\mathrm{g} \%)\end{array}$ & $\begin{array}{c}\text { Total cholesterol } \\
(\mathrm{mg} \%)\end{array}$ & $\begin{array}{c}\text { Blood urea nitrogen } \\
(\mathrm{mg} \%)\end{array}$ \\
\hline- & 2.73 & 114.8 & $2.22 \mathrm{a}$ \\
+ & $1.45 \mathrm{~b}$ & $57.3 \mathrm{~b}$ & $1.01 \mathrm{~b}$ \\
\hline
\end{tabular}

Means within each column bearing at least one common superscript do not differ significantly $(\mathrm{p}<0.01)$

Table 4. Effect of AFB1 on hematology and serum chemistry, as noted in recent studies

\begin{tabular}{|c|c|c|c|c|c|}
\hline \multirow{2}{*}{$\begin{array}{l}\text { AFB1 Level } \\
\text { (ppm) }\end{array}$} & \multirow{2}{*}{ Bird Type } & \multirow{2}{*}{$\begin{array}{l}\text { Age } \\
\text { (days) }\end{array}$} & \multicolumn{2}{|c|}{ Hematology and Serum Chemistry } & \multirow[t]{2}{*}{$\begin{array}{c}\text { Year of Study and } \\
\text { Reference }\end{array}$} \\
\hline & & & Effects & No Effects & \\
\hline $0,0,1$ & 'Ross308 & $427-457$ & $\downarrow \mathrm{AP}$ & $\begin{array}{l}\text { AST, } \gamma \text {-GT, TP, Chl, BUN, } \\
\text { creatinine }\end{array}$ & $\begin{array}{l}\text { (Raju and Devegowda, } \\
\text { 2000, Matur et.al., } \\
\text { 2010). }\end{array}$ \\
\hline $0,0,3$ & Broilers & $1-35$ & $\begin{array}{l}\downarrow \text { TP and Chl at } 21 \text { days } \\
\downarrow \text { TP, Chl, } \gamma \text {-GT, AST at } 35 \\
\text { days }\end{array}$ & $\begin{array}{l}\text { BUN, ALT, } \gamma \text {-GT, AST at } 21 \\
\text { days. BUN, ALT, Hb at } 35 \\
\text { days }\end{array}$ & (Tedesco et. al., 2004). \\
\hline $0,0,8$ & $\sigma^{1}$ Broilers & $14-49$ & $\downarrow$ ALT & $\begin{array}{l}\text { TP,albumin, globulin, Glc., } \\
\text { AST, } \gamma-G T, C a, P\end{array}$ & (Kipper et al., 2011). \\
\hline
\end{tabular}

From the presented data, it is apparent that AFB1 at levels of up to $0.3 \mathrm{mg} / \mathrm{kg}$ decreases serum cholesterol levels. As the dietary level of AFB1 increases to 1 $\mathrm{mg} / \mathrm{kg}$, total serum protein and albumin contents are decreased. At further higher levels of $2 \mathrm{mg} / \mathrm{kg}$ diet, lower serum glucose, $\mathrm{Ca}$, and inorganic $\mathrm{P}$ levels are recorded. From the presented data, it is also not possible to draw a dose-effect relationship for levels of serum enzymes including alkaline phosphatase, alanine transferase, $\gamma$-glutamyl transferase. However, altered concentrations of these enzymes are usually noted at 1 mg AFB $1 / \mathrm{kg}$ diet.

Table 5. Summary of the response of broiler performance to dietary aflatoxin

\begin{tabular}{|c|c|c|c|c|c|c|}
\hline \multirow[b]{2}{*}{$\mathrm{AF}(\mathrm{mg} / \mathrm{kg})$} & \multicolumn{3}{|c|}{ Changes in performance } & \multirow[b]{2}{*}{ AF source } & \multirow[b]{2}{*}{ Duration } & \multirow[b]{2}{*}{ Reference } \\
\hline & $\operatorname{ADG}(g / d)$ & $\operatorname{ADFI}(\mathrm{g} / \mathrm{d})$ & $\begin{array}{c}\text { Feed/gain } \\
(\mathrm{g} / \mathrm{g})\end{array}$ & & & \\
\hline 0.3 & -11.80 & -14.26 & +0.07 & Cultured material & $5 \mathrm{wks}$ & (Raju and Devegowda 2000). \\
\hline 0.4 & -5.48 & --- & --- & Unknown origin & 7 wks & (Raju and Devegowda 2000). \\
\hline 0.5 & -1.35 & -0.16 & +0.11 & Cultured material & 7 wks & (Verma et al, 2007). \\
\hline 0.5 & -4.6 & No effect & +0.18 & Cultured material & 5 wks & (Manafi et al, 2012). \\
\hline 0.675 & -2.295 & --- & --- & Cultured material & 7 wks & (Raju and Devegowda 2000). \\
\hline 0.81 & -0.48 & -0.16 & +0.11 & $\begin{array}{l}\text { Naturally } \\
\text { contaminated }\end{array}$ & 5 wks & (Verma et al, 2007). \\
\hline 1 & -5.12 & -5.16 & +0.26 & Cultured material & 7 wks & (Verma et al, 2004). \\
\hline 1.14 & -2.6 & 0.19 & +0.13 & Naturally contaminated & $6 \mathrm{wks}$ & (Shi et al, 2009). \\
\hline 2 & -3.7 & --- & --- & Cultured material & 3 wks & (Basmacioglu et al, 2005). \\
\hline 4 & -9.33 & -10.38 & +0.04 & Purified AFB1 & 3 wks & (Ledoux et al, 1999). \\
\hline 5 & -8.5 & --- & +0.35 & Purified AFB1 & $3.4 \mathrm{wks}$ & (Verma et al, 2007). \\
\hline
\end{tabular}

The aflatoxin reduces weight gain and feed intake, and worsens feed efficiency. The response of poultry to AF-contaminated feed depends on the AF dose. 


\section{EFFECT OF AFLATOXIN ON LAYING HENS}

$\mathrm{AF}$ also can affect laying hens and lead to reduced egg production, poor egg quality and increased mortality of challenged hens. AFB1 adversely influences egg quality by decreasing shell thickness, egg weight and egg energy deposition. The negative impacts of AF on laying hens can be induced when feed contains 1-2 mg/kg (Azzam and Gabal, 1998). In addition, AF in laying hen feed can result in an $\mathrm{AF}$ residue in the eggs (feed to egg AFB1 transmission ratio was approximately 5000:1); therefore it is very important to control $\mathrm{AF}$ concentrations in feeds for laying hens.The egg production and egg quality were resulted from using AFB1 contaminated chicken diet in feeding laying hens. AFB1 residue in laying hens' tissues and organs of liver, kidney, breast, legs, and gizzard increased with increasing feed AFB1 concentration. AFB1 and AFT could contaminate the food produced from laying hens or eggs raised on $\mathrm{AF}$ contaminated feed. Additionally, litter generated from chicken fed artificially contaminated AFB1 had high AF residues and the level increased with increasing AFB1 contamination diet.

Table 6. Aflatoxin B1 content of eggs from hens fed aflatoxin contaminated feeds (Herzallah 2013)

\begin{tabular}{|c|c|c|c|}
\hline \multirow{2}{*}{$\begin{array}{l}\text { Description } \\
\text { Sample }\end{array}$} & \multicolumn{3}{|c|}{ Treatment } \\
\hline & T1 B1 (ppb) & T2 B1 (ppb) & T3 B1 (ppb) \\
\hline Feed & $894.12 \mathrm{a} \pm 5.12$ & $395.31 \mathrm{a} \pm 3$ & $190.02 \mathrm{a} \pm 3.16$ \\
\hline Eggs & $0.66 \mathrm{~d} \pm 0.11$ & $0.43 c \pm 0.21$ & $0.33 \mathrm{~d} \pm 0.12$ \\
\hline Breast & $0.72 \mathrm{~d} \pm 0.19$ & $0.52 \mathrm{c} \pm 0.17$ & $0.33 \mathrm{~d} \pm 0.08$ \\
\hline Liver & $1.59 \mathrm{c} \pm 0.14$ & $0.86 c \pm 0.13$ & $0.46 \mathrm{~cd} \pm 0.07$ \\
\hline Kidney & $0.88 \mathrm{~d} \pm 0.13$ & $0.59 \mathrm{c} \pm 0.12$ & $0.44 \mathrm{~cd} \pm 0.11$ \\
\hline Legs + Thigh & $0.78 \mathrm{~d} \pm 0.12$ & $0.45 \mathrm{c} \pm 0.11$ & $0.30 \mathrm{~d} \pm 0.12$ \\
\hline Gizzard & $1.22 \mathrm{c} \pm 0.16$ & $0.84 c \pm 0.12$ & $0.76 c \pm 0.12$ \\
\hline Litter & $26.06 \mathrm{~b} \pm 0.17$ & $16.30 \mathrm{~b} \pm 2.01$ & $6.50 \mathrm{~b} \pm 1.04$ \\
\hline
\end{tabular}

EFFECT AFLATOXINS ON IMMUNE SYSTEM

Aflatoxins works as an inhibitor of protein synthesis and as resulted; destroy cells and tissues with a high protein turnover such as that found in the liver, immune system or gut epithelium, which is most susceptible to the toxic effects of AF. In this way, exposure to AF has been demonstrated to suppress the immune response in poultry.AF can inhibits the development of the thymus gland or effect the relative weight of the bursa of Fabricius, which may result in serious deficiencies in both cellular and antibody responsiveness of the chicken immune system (Celik et al, 2000). Inhibition of macrophage functions, T lymphocyte activity or cytokine expression by $\mathrm{AF}$ results in vaccine failure or pathogen persistence, as exemplified in many studies by reduced immunoglobulin production (Yunus et al, 2008). Recent epidemiological data indicates a high correlation between outbreaks of Newcastle disease and AF contamination of broiler rations (Yunus et al, 2008). In general, the dose of AFB1 needed to affect the immune system is considered less than the dose required to elicit a reduction in bird performance. The threshold dose of AFB 1 is reported to be approximately 0,4 and $1 \mathrm{mg} / \mathrm{kg}$ for the negative effects on cell mediated and humoral immunity, respectively, in broilers (Yunus et al, 2008). Contaminated with low AF content may pose a serious risk to animal health, increasing susceptibility to infections or reducing vaccination efficacy.

Table 7. Residual effect of mycotoxin-contaminated feed on eggs and poultry flesh total aflatoxins (AFT) total aflatoxins (AFT) (Herzallah 2013) $1,2,3$

\begin{tabular}{|c|c|c|c|c|}
\hline Sample $^{4}$ & AFT (ppb) & $\mathrm{T} 1$ & $\mathrm{~T} 2$ & 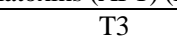 \\
\hline Feed & & $965.12 \mathrm{a} \pm 3.11$ & $467.27 \mathrm{a} \pm 4.01$ & $192.61 \mathrm{a} \pm 3.14$ \\
\hline Eggs & & $1.54 \mathrm{bc} \pm 0.25$ & $0.71 b \pm 0.29$ & $0.42 \mathrm{~b} \pm 0.21$ \\
\hline Breast & & $0.63 \mathrm{~d} \pm 0.09$ & $<0.054$ & $<0.05$ \\
\hline Liver & & $2.12 b \pm 0.21$ & $1.02 b \pm 0.12$ & $0.51 b \pm 0.16$ \\
\hline Kidney & & $1.41 \mathrm{c} \pm 0.19$ & $0.61 b \pm 0.10$ & $0.47 \mathrm{~b} \pm 0.09$ \\
\hline Legs & & $1.01 \mathrm{~cd} \pm 0.11$ & $0.41 b \pm 0.02$ & $<0.05$ \\
\hline Gizzard & & $1.20 \mathrm{~cd} \pm 0.11$ & $<0.05$ & $<0.05$ \\
\hline
\end{tabular}

${ }^{1}$ Values are mean of three readings SD; ${ }^{2}$ Values of differentsuperscript letter within column are significantly differ at $\mathrm{p}<0.05$;

${ }^{3}$ Total aflatoxins represent the sum values of B1, B2, G1 and G2; ${ }^{4}$ Control samples contain $<0.05 \mathrm{ppb}$

\section{EFFECTS OF AFLATOXIN} GASTROINTESTINAL TRACT

Gastrointestinal tract is the first site where contact and absorption of feed that contaminated with aflatoxin and should be expected to be affected by AFB1 with greater potency as compared to other organs. However, this aspect of aflatoxicosis is the often neglected area of mycotoxin research and available literature is nonconclusive. Various studies documenting effects of AFB1 on weight and histological characteristics of different segments of GIT are summarized in Table 8. The weights of proventriculus, gizzard, and pancreas relative to body weight of broilers have not been reported to be affected at levels of AFB1 up to $3,5 \mathrm{mg} / \mathrm{kg}$ diet. However, at a 
dietary level of $4 \mathrm{mg} \mathrm{AFB} 1 / \mathrm{kg}$ or higher, the relative weight of these organs has been noted to decrease by some authors, while increase by other. However, Edrington et al. (1997) could not find any effect of $4 \mathrm{mg}$ AFB1/kg diet on the relative weight of gizzard and pancreas. Literature on the effects of AFB1 on histology of GIT is scanty and not conclusive. In this regard, the density of whole intestine (weight/length) has been reported to decrease after 3 weeks of dietary exposure to AFB1 at levels as low as $0.02 \mathrm{mg} / \mathrm{kg}$ and $0,7 \mathrm{mg} / \mathrm{kg}$ As the width of muscularis tends of be relatively constant, the density of intestine could be a good indicator of unit absorptive area. On this variable, the effects of higher AFB1 dosage in broilers are not known. At higher levels of $1 \mathrm{mg}$ AFB1/kg diet, Kumar and Balachandran (2009) however noted catarhal enteritis with lymphocytic or mononuclear cell infiltrations in the intestine of broilers fed on the toxin contaminated ration for 4 weeks contrary to these reports, no histopathological changes in duodenum, jejunum, cecum, and ileum could be noted by Ledoux et al. (1999) when male broilers were exposed to $4 \mathrm{mg}$ AFB1/kg diet for 3 weeks. Similarly, breaking strength, size, and collagen content of large intestine was not found to be affected in broilers (male Cobb $\times$ Cobb; exposure age 1 to 21 days) exposed to 0 , $0,6,1,2,2,5,5,0$, and $10 \mathrm{mg}$ AFB1/kg diet. Lipid content of large intestine was decreased only at the highest level of AFB1 $(10 \mathrm{mg} / \mathrm{kg})$ in report. From the mentioned studies, it is difficult to draw a dose-effect relationship between AFB1 and histological changes in the GIT. This is because specific sections of GIT, studied variables, and length of exposure were different in the aforementioned studies. Furthermore, the type and specific line of chicken used in various studies may also affect the reaction of intestine towards chronic aflatoxicosis. This hypothesis is supported by the recent observations regarding aflatoxicosis in layers (Hyline W36; exposure age from 140 to 154 days) by Applegate et al. (2009). Contrary to the observations in broilers, these authors noted a linear increase in the crypt depth in distal jejunum with the increasing levels of AFB1 in the diet as $0,0,6,1,2$, and $2,5 \mathrm{mg} / \mathrm{kg}$, but no effect of the toxin on villus height and number of toxins.

Table 8. Weight and histology of individual segments of gut in chicken during exposure to AFB1

\begin{tabular}{|c|c|c|c|c|c|}
\hline \multirow{2}{*}{$\begin{array}{l}\text { AFB1 level } \\
\quad(\mathrm{ppm})\end{array}$} & \multirow{2}{*}{ Bird Type } & \multirow{2}{*}{ Age (days) } & \multicolumn{2}{|c|}{ Characteristics of Gut } & \multirow{2}{*}{$\begin{array}{l}\text { Year of Study and } \\
\text { Reference }\end{array}$} \\
\hline & & & Effects & No Effects & \\
\hline $0.07,0.7$ & ôss 308 & $7-29$ & $\downarrow$ Density of duodenum and jejunum & $\begin{array}{l}\text { Weight of proventriculus } \\
\text { and gizzard }\end{array}$ & (Yunus et. al 2008). \\
\hline 0.02 & \% Hybro, & $21-49$ & $\downarrow$ Density of intestine & $\begin{array}{l}\text { Gizzard weight; intestinal } \\
\text { weight and length }\end{array}$ & (Kana et. al 2010). \\
\hline 0.1 & ôsoss308, & $427-457$ & - & Pancreas weight & (Yunus et. al 2008). \\
\hline 0.3 & Broilers, & $1-35$ & - & Gizzard weight & $\begin{array}{l}\text { (Raju and Devegowda } \\
2000 \text { ). }\end{array}$ \\
\hline 1 & Broiler, & $1-28$ & $\begin{array}{l}\text { Necrosis/fibrosis in crop and } \\
\text { proventriculus. Catarrhal enteritis in } \\
\text { intestine }\end{array}$ & - & $\begin{array}{l}\text { (Kumar and } \\
\text { Balachandran 2009). }\end{array}$ \\
\hline $\begin{array}{ll}0.6, & 1.2 \\
2.5 & \end{array}$ & q W & $\begin{array}{l}36 \\
140,154\end{array}$ & $\begin{array}{l}\text { linear effect: } \uparrow \text { crypt length in distal } \\
\text { jejunum }\end{array}$ & $\begin{array}{l}\text { Number and density of } \\
\text { goblet cell in jejunum }\end{array}$ & $\begin{array}{l}\text { (Applegate et. al } \\
\text { 2009). }\end{array}$ \\
\hline 3.5 & Broilers, & $1-2$ & - & Gizzard weight & (Kubena et. al 1997 ) \\
\hline 4 & ${ }^{\lambda}$ PetxHubb & $1-21$ & - & Gizzard and pancreas weight & (Edrington et.al 1997). \\
\hline 4 & $\widehat{o}$ Broilers & $1-21$ & $\uparrow$ Proventriculus and pancreas weight & $\begin{array}{l}\text { Microscopic evaluation of } \\
\text { pancreas and whole GIT }\end{array}$ & (Ledoux et. al 1999). \\
\hline 5 & AA $x$ Pet & $1-21$ & $\uparrow$ Gizzard and pancreas weight & Proventriculus weight & (Bailey et. al 1998). \\
\hline 5 & Broilers & $1-21$ & $\uparrow$ Proventriculus and pancreas weight & - & (Kubena et.al 1998). \\
\hline $\begin{array}{l}0,0.6,1.2 \\
2.5,5,10\end{array}$ & ¿CobbxCobb & $1-21$ & - & $\begin{array}{l}\text { Breaking strength and size of } \\
\text { large intestine }\end{array}$ & (Warren et.al 1980). \\
\hline
\end{tabular}

\section{CONCLUSION}

The presence of mycotoxins in poultry diets can determine the losses in poultry production system. From the harvest of grain, the effects of fungal contamination and mycotoxicological can be perceived, and its effects can reflect on the production of chickens. The control depends on the application the policies in the agricultural management, production systems and storage, which are the root of the problem. Research in these areas should be developed, reflecting better results in economic and productive poultry, but also for the improvement of health food for human consumption.

\section{REFERENCES}

Applegate, T.J., Schatzmayr, G., Pricket, K., Troche, C., Jiang, Z. 2009. Effect of aflatoxin culture on intestinal function and nutrient loss in laying hens. Poult. Sci., 88: $1235-1241$.

Azzam, A.H., Gabal, M.A. 1998. Aflatoxin and immunity in layer hens. Avian Pathol., 27: 570-577.

Bailey, R., Kubena, L., Harvey, R., Buckley, S., Rottinghaus, G. 1998. Efficacy of various inorganic sorbents to reduce the toxicity of aflatoxin and T-2 toxin in broiler chickens. Poult. Sci., 77: 1623-1630.

Basmacioglu, G., Oguz, H., Ergul, M., Col, R., Birdane, Y. O. 2005. Effect of dietary esterified glucomannan on 
performance, serum biochemistry and haematology in broiler exposed to aflatoxin. Cz. J. of An. Sci., 20:31-39.

Bintvihok, A. 2001. Controlling aflatoxin danger to duck and duck meat. World Poultry Sci. J., 17:18-20.

Celik, I., Oguz, H., Demet, O., Donmez, H. H., Boydak, M., Sur, E. 2000. Efficacy of polyvinylpolypyrrolidone in reducing the immunotoxicity of aflatoxin in growing broilers. Br. Poult. Sci., 41:430-439.

Diaz, G. J., Murcia, H. W. 2011. Biotransformation of aflatoxin B1 and its relationship with the differential toxicological response to aflatoxin in commercial poultry species. Aflatoxins-Biochemistry and Molecular Biology. Ramon G. Guevara-Gonzalez (Ed.). ISBN: 978-953-307-395-8, InTech.

Edrington, T.S., Kubena, L.F., Harvey, R., Rottinghaus, G.E. 1997. Influence of a superactivated charcoal on the toxic effects of aflatoxin or T-2 toxin in growing broilers. Poult. Sci., 76: 1205-1211.

Edrington, T.S., Kubena, L.F., Harvey, R.B., Rottinghaus, G.E 1997. Determination of aflatoxin in eggs, milk, meat and meat products using HPLC fluorescent and UV detectors. Food Chemistry, 114-118.

Gowda, N.K.S., Ledoux, D.R., Rottinghaus, G.E., Bermudez, A.J., Chen, Y.C. 2008. Efficacy of turmeric (curcuma longa), containing a known level of curcumin, and a hydrated sodium calcium aluminosilicate to ameliorate the adverse effects of aflatoxin in broiler chicks. Poult. Sci., 87:1125-1130.

Grenier, B., Applegate, T.J. 2013. Modulation of intestinal functions through the mycotoxin ingestion. MetaAnalysis of Published Experiments in Animals. Toxins, 5(2):396-430.

Herzallah, S.M., 2013. Aflatoxin B1 Residues in Eggs and Flesh of Laying Hens Fed Aflatoxin B1 Contaminated Diet. American J. of Agric. and Bio. Sci. 8(2): 156-161.

Kana, J.R,, Teguia, A., Tchoumboue, J. 2010. Effect of dietary plant charcoal from Canarium schweinfurthii Engl. and maize cob on aflatoxin B1 toxicosis in broiler chickens. Adv. Anim. Biosci., 1:462-463.

Kipper, M., Lehnen, C. R., Hauschild, L., Vale, M. M., Lovatto, P. A. 2011. Meta-analytical study of productive and nutritional interactions of mycotoxins in broilers. Poultry Science, 90, 1934-1940.

Kubena, L.F., Harvey, R., Bailey, R., Buckley, S., Rottinghaus, G.E 1998. Effects of a hydrated sodium calcium aluminosilicate (T-Bind) on mycotoxicosis in young broiler chickens. Poult. Sci., 77(10):1502-1509.

Kubena, L.F, Harvey, R., Buckley, S. Edrington, T., Rottinghaus, G. E. 1997. Individual and combined effects of moniliformin present in Fusarium fujikuroi culture material and aflatoxin in broiler chicks. Poult. Sci., 76(2): 265-270.

Kumar, R., Balachandran, C. 2009. Histopathological changes in broiler chickens fed aflatoxin and cyclopiazonic acid. Vet. Arhiv., 79, 31-40.

Ledoux, D. R., Rottinghaus, G. E., Bermudez, A. J., AlonsoDebolt, M. 1999. Efficacy of a hydrated sodium calcium aluminosilicate to ameliorate the toxic effects of aflatoxin in broiler chicks. Poult. Sci., 78:204-210.
Manafi, M., Umakantha, M., Noor Ali, M., Narayana Swamy, H. D. 2012. Study of the combination effects of aflatoxin and T-2 Toxin on performance parameters and internal organs of commercial broilers. Global Veterinaria, 8:393-396.

Matur, E., Ergul, E., Akyazi, I., Eraslan, E., Cirakli, Z.T., 2010. The effects of Saccharomyces cerevisiae extract on the weight of some organs, liver, and pancreatic digestive enzyme activity in breeder hens fed diets contaminated with aflatoxins. Poult. Sci, 89:22132220.

Nelson, T.S., Johnson, Z.B., Kirby, L.K., Beasley, J.N. 1982. Digestion of dry matter and amino acids and energy utilization by chicks fed molded corn containing mycotoxins. Poult. Sci., 61, 584-585.

Raju, M.V.L.N., Devegowda, G. 2000. Influence of esterified-glucomannan on performance and organ morphology, serum biochemistry and haematology in broilers exposed to individual and combined mycotoxicosis (aflatoxin, ochratoxin and T-2 toxin). Br. Poult. Sci., 41, 640-650.

Shi, Y., Xu, Z., Sun, Y., Wang, C., Feng, J. 2009. Effects of two different types of montmorillonite on growth performance and serum profiles of broiler chicks during aflatoxicosis. T. J. of Vet. \& Ani. Sci., 33:15-20.

Smith, E.E., Kubena, L.F., Braithwaite, R.B., Harvey, R.B., Phillips, Sodhi, S., Brar, A. P. S., Grewal, G. S. 1996. Biochemical studies on combined immunomodulatory effects of aflatoxin and malathion in broiler chicks. Indian J. of Poultry Sci., 31: 88-91.

Sumit R., Kim, J.E, Coulombe, R., Jr. 2010. Aflatoxin B1 in poultry: Toxicology, metabolism and prevention. Research in Vet. Sci., 89(3):325-331.

Tedesco, D., Steidler, S., Galletti, S., Tameni, M., Sonzogni, O., Ravarotto, L. 2004. Efficacy of silymarin-phospholipid complex in reducing the toxicity of aflatoxin B1 in broiler chicks. Poult. Sci., 83:1839-1843.

Warren, M.F., Hamilton, P.B. 1980. Intestinal fragility during ochratoxicosis and aflatoxicosis in broiler chickens. Appl. Environ. Microbiol., 40:641-645.

Van Egmond, H.P., Jonker, M.A. 2004. Worldwide regulations on aflatoxins-the situation in 2002. J. Toxicol. Toxin Rev. 23(2, 3):273-293.

Verma, J., Johri, T. S., Swain, B. K., Ameena, S. 2004. Effect of graded levels of aflatoxin, ochratoxin and their combinations on the performance and immune response of broilers. British Poultry Sci., 45:512-518.

Verma, J., Johri, T. S., Swain, B. K. 2007. Effect of aflatoxin, ochratoxin and their combination on protein and energy utilisation in white leghorn laying hens. J. of the Science of Food and Agriculture, 87: 760-764.

Yunus, A.W., Nasir, M.K., Farooq, U., Böhm, J. 2008. Prevalence of poultry diseases in district Chakwal and their interactrion with mycotoxicosis: 1 . Effects of age and flock size. J. Anim. Plant Sci., 18:107-113.

Zain, M. E. 2011. Impact of mycotoxins on humans and animals. J. of Saudi Chemical Society, 15:129-144. 